\title{
Vasomotor responses to hypoxia and cold air
}

\author{
Heather C Massey*, James R House, Michael J Tipton \\ From 15th International Conference on Environmental Ergonomics (ICEE XV) \\ Portsmouth, UK. 28 June - 3 July 2015
}

\section{Introduction}

At altitude, hypoxia coexists with other environmental stressors, in particular cold. Cold injury $(\mathrm{CI})$ remains a frequent pathological consequence of exposure to altitude $(>2800 \mathrm{~m})[1]$. A number of studies $[2,3]$ have examined extremity vasomotor responses during local cold stress in controlled laboratory conditions at high altitude and have suggested that systemic arterial hypoxia exaggerates cold-induced cutaneous vasoconstriction and impairs any cold-induced vasodilatation (CIVD) response. Recently, Keramides et al. [4] reported that hypoxic exposure impairs the local rewarming response of the hands. In this way, hypoxia increases the risk of $\mathrm{CI}$ for a given temperature, but this hypothesis has not been tested in a dynamic air environment or during whole body exposure to the thermal stimulus, similar to that when at altitude. It is this dynamic response which determines the 'dose' of cold experienced by the extremities and thereby the risk of CI. It was hypothesized that vasoconstriction and vasodilatation would occur at warmer skin temperatures when breathing a hypoxic compared to normoxic gas mixture.

\section{Methods}

Fourteen volunteers (males and females) gave their informed consent to participate in the ethically approved study during which they wore shorts and a t-shirt then inspired normoxic air $\left(\mathrm{F}_{\mathrm{I}} \mathrm{O}_{2}: 0.209[\mathrm{~N}]\right)$, or a hypoxic gas mixture $\left(\mathrm{F}_{\mathrm{I}} \mathrm{O}_{2}: 0.113[\mathrm{H}]\right)$ in a balanced order. Throughout gradual cooling $\left(-26^{\circ} \mathrm{C} \cdot \mathrm{hr}^{-1}\right)$ and rewarming $\left(28.5^{\circ} \mathrm{C} . \mathrm{hr}^{-1}\right)$ phases, skin temperatures $\left(\mathrm{T}_{\mathrm{sk}}\right)$ were measured continuously (at the chest, arm, thigh, exposed calf, right index finger and right great toe) with skin thermistors, and laser Doppler skin blood flow measured on the right great toe, little toe, thumb and little finger. Assessment of the onset and maximal vasoconstriction,

\footnotetext{
* Correspondence: heather.massey@port.ac.uk

Extreme Environments Laboratory, Department of Sport and Exercise
} Science, University of Portsmouth, Portsmouth, UK and onset of vasodilatation were made by independent visual inspection by two researcers, using a priori definitions; mean skin temperatures $\left(\mathrm{T}_{\mathrm{msk}}\right)$ at these points were compared.

\section{Results}

During the cooling phase, the onset of vasoconstriction of the thumb and little finger occurred at higher $\mathrm{T}_{\text {msk }} \mathrm{H}$ than $\mathrm{N}$ (thumb; $\mathrm{H}, 34.27[0.78]{ }^{\circ} \mathrm{C}, \mathrm{N}, 33.83[0.82]{ }^{\circ} \mathrm{C} \mathrm{p}=0.021$; little finger; $\left.\mathrm{H} 34.15[1.06]{ }^{\circ} \mathrm{C}, \mathrm{N}, 33.37[0.89]{ }^{\circ} \mathrm{C}, \mathrm{p}=0.009\right)$. Maximal vasoconstriction of the thumb and little finger occurred at higher $\mathrm{T}_{\mathrm{msk}}$ in hypoxia than normoxia (thumb; $\mathrm{H}, 32.00[1.43]{ }^{\circ} \mathrm{C}, \mathrm{N}, 31.08[1.31]^{\circ} \mathrm{C} \mathrm{p}=0.025$; litthe finger; $\left.\mathrm{H} 32.39[1.09]{ }^{\circ} \mathrm{C}, \mathrm{N}, 31.58[1.25]{ }^{\circ} \mathrm{C}, \mathrm{p}=0.003\right)$. Greater $\mathrm{T}_{\text {sk }}$ was observed at the onset of vasoconstriction in the little toe $\left(\mathrm{H}, 34.63[0.85]{ }^{\circ} \mathrm{C}, \mathrm{N}, 33.87[0.95]{ }^{\circ} \mathrm{C}\right.$ $\mathrm{p}=0.001$ ), but was not seen at maximal vasoconstriction or at any point on the great toe. The onset of vasodilatation occurred at a warmer $\mathrm{T}_{\mathrm{msk}}$ in $\mathrm{H}$ compared to $\mathrm{N}$ in the thumb $\left(\mathrm{H}, 32.82[1.88]{ }^{\circ} \mathrm{C}, \mathrm{N}, 32.01[1.65], \mathrm{p}=0.011\right)$ and little finger $\left(\mathrm{H}, 32.78[1.95]{ }^{\circ} \mathrm{C}, \mathrm{N}, 32.05[1.72]{ }^{\circ} \mathrm{C}\right.$, $\mathrm{p}=0.006$ ), but not in the great toe or little toe.

\section{Discussion}

Acute exposure to normobaric hypoxia in combination with whole body cooling resulted in vasoconstriction at warmer Tsk compared to a normoxic condition in the hands but not the feet with the exception of the little toe. Similarly, the onset of vasodilatation occurred at higher $\mathrm{T}_{\mathrm{sk}}$ in hypoxia than normoxia in the hands only. Therefore, in general, the hypothesis can be accepted for the hands, but not the feet. The reason for the different responses of the hands and feet is not clear, but may relate to the greater sensitivity of the feet to cooling resulting in vasoconstriction at higher $\mathrm{T}_{\mathrm{sk}}$ in all conditions.

\section{Conclusion}

Hypoxia and gradual cooling results in vasomotor responses which increase the 'dose of cold' experienced 
at the extremities, primarily the hands, and therefore increases the risk of $\mathrm{CI}$.

\section{Acknowledgements}

The authors would like to thank Gaizka Mejuto for his help on this project.

Published: 14 September 2015

\section{References}

1. Harirchi I, Arvin A, Vash JH, Zafarmand V: Frostbite: incidence and predisposing factors in mountaineers. Br J Sports Med 2005, 39(12):898-901.

2. Takeoka M, Yanagdaira Y, Sakai A, Asano K, Fujiwara T, Yanagisawa K, et al: Effects of high altitudes on finger cooling test in Japanese and Tibetans at Qinghai Plateau. Int J Biometeorol 1993, 37(1):27-31.

3. Purkayastha SS, Sharma RP, llavazhagan G, Sridharan K, Ranganathan S, Selvamurthy W: Effect of vitamin C and E in modulating peripheral vascular response to local cold stimulus in man at high altitude. Jpn J Physiol 1999, 49(2):159-167.

4. Keramides M, Kolegard R, Mekjavic I, Eiken O: Acute effects of normobaric hypoxia on hand-temperature responses during and after local cold stress. High Alt Med Biol 2014, 15(2):183-191.

doi:10.1186/2046-7648-4-S1-A53

Cite this article as: Massey et al:: Vasomotor responses to hypoxia and cold air. Extreme Physiology \& Medicine 2015 4(Suppl 1):A53.

\section{Submit your next manuscript to BioMed Central} and take full advantage of:

- Convenient online submission

- Thorough peer review

- No space constraints or color figure charges

- Immediate publication on acceptance

- Inclusion in PubMed, CAS, Scopus and Google Scholar

- Research which is freely available for redistribution

Submit your manuscript at www.biomedcentral.com/submit 